\title{
Utility of heterologous microsatellite markers for population genetic studies on tropical species of Asteraceae
}

\author{
G.G. Weber, D.L. Lima, L. Pilati, A. Silvério and P.R. Da-Silva \\ Departamento de Ciências Biológicas, Laboratório de Genética e Biologia \\ Molecular Vegetal, Universidade Estadual do Centro-Oeste, Guarapuava, \\ PR, Brasil
}

Corresponding author: P.R. Da-Silva

E-mail:prsilva@unicentro.br

Genet. Mol. Res. 19 (2): gmr18546

Received April 16, 2020

Accepted April 30, 2020

Published May 30, 2020

DOI http://dx.doi.org/10.4238/gmr18546

\begin{abstract}
The Asteraceae have high ecological importance in the threatened Atlantic Forest biome, as most species are pioneers and nectar-producing plants. Using population genetic data could help develop adequate conservation strategies for species and biomes. However, no genetic data or microsatellite markers are available for most Atlantic Forest native Asteraceae species. In their absence, heterologous microsatellite markers could help conduct population genetic studies of less studied species. We evaluated the transferability and utility for population studies of 15 anonymous microsatellite primers pairs developed from other Asteraceae to four others, three of which are important in folk medicine (Baccharis milleflora, Baccharis articulata, Baccharis dracunculifolia) and a toxic species of veterinary importance (Senecio brasiliensis). We found that the microsatellite primers had high transferability to phylogenetically close Asteraceae species. Transferability rates were below those reported for other plant families. The transferred microsatellite primers gave low polymorphism frequencies and high null allele frequencies in the populations. A major factor contributing to this low transferability and high frequency of null alleles is probably the high genetic variation of tropical Asteraceae.
\end{abstract}

Key words: Atlantic Forest; Null alleles; SSR cross-amplification; Transferability; Conservation 


\section{INTRODUCTION}

The Atlantic Forest is one of the most biodiverse tropical biomes on the planet and is also one of the most threatened (Mittermeier et al., 2004; Liebsch et al., 2008). From the time of the European colonization of Brazil in the fifteenth century, the lands occupied by this biome went through successive cycles of economic exploitation and urban and agroindustrial expansions. These interferences have reduced the vegetation of this biome to only $11 \%$ of the area that it originally occupied (Ribeiro et al., 2009).

Currently, about $70 \%$ of the Brazilian population (120 million people, responsible for $80 \%$ of the country's gross domestic product), live in an original Atlantic Forest domain (MMA, 2018). This extensive occupation and exploitation of this biome have led to the reduction and degradation of habitats, putting the native species at risk. This is even more evident considering the fact that although the Atlantic Forest occupies only $15 \%$ of the Brazilian territory, $60 \%$ of the endangered species in Brazil are from this biome (MMA, 2018). One of the most serious effects of the long history of occupation of the Atlantic Forest has been the isolation of the species affected by the fragmentation and destruction of habitats. This fragmentation may result in loss of genetic variability due to genetic drift, reduced gene flow and inbreeding (Zuchi et al., 2003).

Genetic variability is one of the fundamental characteristics of a population; it is what makes possible the evolutionary process (Sala et al., 2000). Decreasing the genetic variability of a population can diminish its adaptive capacity, thus putting the species at the risk of extinction. Therefore, knowledge of the genetic variability in natural populations is an important step to assist in the decision-making process for the implementation of conservation and management strategies (Lynch and Milligan, 1994; Bittencourt and Sebbenn, 2009; Brandão et al., 2011; Lopez and Gonzaga, 2014).

Several techniques have been developed over time to quantify the genetic variability of populations. Currently molecular markers are the most commonly used, especially microsatellites, also known as SSRs (simple sequence repeats). These markers can be developed using both genomic DNA and expressed sequences; the latter are termed EST-SSRs (expressed sequence tag- simple sequence repeats) and have been reported to be transferable to a wider range of species (Ellis and Burke, 2007). The use of this type of marker is mainly because of its practicality, robustness, and reliability. In addition, these markers are codominant, multi-allelic, highly reproducible, and PCR-based (polymerase chain reaction) (Oliveira et al., 2006). However, because the amount of investment and work required to develop microsatellite primers are high, priority has been given to species with greater economic importance. Thus, microsatellite primers have been developed for a limited number of native species.

An important solution to the lack of microsatellite markers specific to native species is the transfer of the primer pairs originally designed for a particular taxon to other phylogenetically related species (Kuleung et al., 2004; Ellis and Burke, 2007; Varshney et al., 2007). The transferability of markers depends on the conservation of flanking regions on primer binding sites in different taxa (Da-Silva et al., 2011). Several studies have shown high degrees of conservation of these flanking regions in tree species, mainly in species of Myrtaceae, which explains the high transferability rate of microsatellite primers designed for this taxon (Miwa et al., 2000; Rosseto et al., 2000; Zuchi et al., 2003; Faria et al., 2010; Ferreira-Ramos et al., 2014; Nogueira et al., 2015; Fagundes et al., 2016). Thus, this 
approach has been suggested as an alternative to obtain genetic data from native species that lack clear economic importance (Ellis and Burke, 2007). For some species of Asteraceae microsatellite primers have been developed, among which we can mention Chromolaena odorata (Yu and Li, 2013), Erigeron lemmonii (Lindsay et al., 2012), Hieracium s.s. (Jonsson et al., 2010), Ambrosia artemisiifolia (Genton et al., 2005), Solidago gigantea (Beck et al., 2014), Erigeron (Takayama et al., 2012), Ligularia hodgsonii (Mao et al., 2009), Hypochaeris salzmanniana (Ruas et al., 2009) and Baccharis dracunculifolia (Belini et al., 2016). Among these, three species are native to the Atlantic forest $C$. odorata, A. artemisiifolia and $B$. dracunculifolia. Therefore, primers developed for these species can be used for transferability to tropical species of Asteraceae.

A 2009 survey of the Atlantic Forest species cataloged 15,782 plant species, of which 7,155 (45\%) are endemic (Stehmann et al., 2009). However, these numbers are likely to increase, as much of the flora of this biome is still unknown to the scientific community. A search of the PUBMED database (https://www.ncbi.nlm.nih.gov/pubmed/) in May 2019 showed that there are microsatellites developed for less than 50 plant species that occur in the Atlantic Forest.

The Asteraceae families are highly represented in the Atlantic Forest with the third highest number of species (910) (Stehmann et al., 2009). Many of the species are herbs or shrubs that are dominant in open areas and / or the forest edges. Most of the Asteraceae are nectar- and pollen-producing plants whose intense flowering aids in the maintenance of pollinating insects, mainly bees. Therefore, in a highly fragmented biome that is in need of conservation efforts, such as the Atlantic Forest, these families are key to the success of efforts in recovering degraded areas and maintaining the fauna. The management and conservation of species in this family can influence several other species, aiding in the maintenance of the ecological stability of the biome. In addition to their ecological importance, many tropical Asteraceae species have medicinal importance and are widely used by the population. Among these species, we can highlight Baccharis milleflora, and Baccharis articulata, popularly known as carqueja (Agostini et al., 2005; Heiden et al., 2009), and B. dracunculifolia, known as alecrim-do-campo, which has a protective action against gastric ulcers (Lemos et al., 2007). Other species are highly toxic and when occurring in pastures pose risks to livestock. One of these species is the Senecio brasiliensis, which is common in Brazilian pastures and causes animal poisoning problems (Habermehl et al., 1988). The use of genetic data, when available, is of great value for the implementation of management and / or conservation strategies. However, for most Atlantic Forest species of Asteraceae, there are no available genetic-population data.

Based on this background, our work had the following objectives: Evaluate the transferability of nuclear microsatellite primers developed from Asteraceae to other Asteraceae species native to the Atlantic Forest; evaluate the usefulness of transferred primers in obtaining genetic and population data of the species.

\section{MATERIAL AND METHODS}

\section{Plant material and DNA extraction}

Four Asteraceae species, all tropical species native to the Atlantic Forest, were used for the transferability tests. The samples were collected from 19 individuals of B. milleflora 
and from 25 individuals of each other species (B. articulata, B. dracunculifolia, and $S$. brasiliensis). The samples from the population of $B$. milleflora were collected in the county of Santos, São Paulo, Brazil, and the other species in the county of Guarapuava, Paraná. Brazil. For each species, leaves and / or stems of plants that were spaced at least $10 \mathrm{~m}$ apart were collected. All collected plant materials were stored in silica gel until DNA extraction.

DNA extraction of all species was performed following the protocol of Doyle and Doyle (1987). After extraction, the DNA concentration and quality of each sample were analyzed by $0.9 \%$ agarose gel electrophoresis followed by staining with ethidium bromide. DNA was quantified by comparing their band intensities with a known amount of $\lambda$ phage DNA $(50,100,200$, and $400 \mathrm{ng})$ as standards.

\section{Microsatellite primers}

A literature review using the PUBMED database (https://www.ncbi.nlm.nih.gov/pubmed/) was carried out to identify studies that had known microsatellite primers in Asteraceae species and performed transferability tests. Among the primers found, preference was given to those that had amplified the highest number of alleles because, once transferred, they have greater potential to differentiate populations. All 15 selected primer pairs (Table 1) were designed to amplify regions of genomic DNA.

Table 1. The 15 nuclear microsatellite loci used to evaluate transferability to the tropical Asteraceae species native to the Atlantic Forest. AT: annealing temperatures according to the original literature.

\begin{tabular}{|c|c|c|c|}
\hline Loci & Primers Sequence (5'- 3') & $\mathbf{A T}^{\circ} \mathbf{C}$ & Source \\
\hline SS20E & $\begin{array}{l}\text { CACACAGACACTCAAAGCTTCA } \\
\text { ACCCGCCCTAAAAATAAAGA }\end{array}$ & $50^{\circ} \mathrm{C}$ & Wieczorek and Gerber (2002) \\
\hline $\mathrm{SS} 24 \mathrm{~F}$ & $\begin{array}{l}\text { AGCTTTTCTTCGCCATTTCCTTCC } \\
\text { AATTTGGTTACTGGGTTTTCTTGA }\end{array}$ & $59^{\circ} \mathrm{C}$ & Wieczorek and Gerber (2002) \\
\hline Eari4-5 & $\begin{array}{l}\text { ATGATGGTGGTGATGAGAAGTC } \\
\text { TGGGTTTCAATGGATTCAAAG }\end{array}$ & $59^{\circ} \mathrm{C}$ & Lindsay et al., (2012) \\
\hline Eari4-6 & $\begin{array}{l}\text { GCGGTTTGTGTAGAAGTCC } \\
\text { ATCTCACTGGTGAATTTCAGAG }\end{array}$ & $57^{\circ} \mathrm{C}$ & Lindsay et al., (2012) \\
\hline 19 & $\begin{array}{l}\text { TTACCCGACTTGCTGAAAGG } \\
\text { CCTTGCGTATTTGCACTCCT }\end{array}$ & $55^{\circ} \mathrm{C}$ & $\mathrm{Yu}$ and $\mathrm{Li}(2013)$ \\
\hline CO189 & $\begin{array}{l}\text { AGAGTAAGCACGAGACCG } \\
\text { AGAACTTTACCTCCCACA }\end{array}$ & $60^{\circ} \mathrm{C}$ & Yu and $\mathrm{Li}(2013)$ \\
\hline $\mathrm{CO} 227$ & $\begin{array}{l}\text { GTTCGTCACCCTTTTCTC } \\
\text { ATCTGCACTTCATCTTCTTC }\end{array}$ & $62^{\circ} \mathrm{C}$ & Yu and $\mathrm{Li}(2013)$ \\
\hline $23 \_(\mathrm{TG}) 3+7 \mathrm{st}$ & $\begin{array}{l}\text { AACCCTAAATCGTATGTGTCTAGTG } \\
\text { CCTCCTTCCGAGCTATGTAGA }\end{array}$ & $58.2^{\circ} \mathrm{C}$ & Jonsson et al., (2010) \\
\hline Amb82 & $\begin{array}{l}\text { AAACAACTAGTGTGTGTTTCAGTGTG } \\
\text { GTCTTCGGCCGTAAAATGAC }\end{array}$ & $60^{\circ} \mathrm{C}^{*}$ & Genton et al., (2005) \\
\hline $\mathrm{Sg} \_2$ & $\begin{array}{l}\text { TCTAAACTGTAAGTCTTTGATGAAACC } \\
\text { GCCGTCAATCCTTACAATCC }\end{array}$ & $65^{\circ} \mathrm{C}^{*}$ & Beck et al., (2014) \\
\hline Sg_6 & $\begin{array}{l}\text { TTTACCTTTGAATTGCGGC } \\
\text { GTTTAGTACCAATCAACCATGGGC }\end{array}$ & $65^{\circ} \mathrm{C}^{*}$ & Beck et al., (2014) \\
\hline $\mathrm{Sg} \_8$ & $\begin{array}{l}\text { TCCCTCTTTATTCTTTCAACAAACC } \\
\text { GTTT AACACCAACATTGCAATCCC }\end{array}$ & $65^{\circ} \mathrm{C}^{*}$ & Beck et al., (2014) \\
\hline ER-HAJZC & $\begin{array}{l}\text { GGATATCGGTTTGGCTTGA } \\
\text { GGAATCCCTTCTCTTTCTGA }\end{array}$ & $63^{\circ} \mathrm{C}^{*}$ & Takayama et al., (2012) \\
\hline Lho35 & $\begin{array}{l}\text { AACCATCGCTGCACATTC } \\
\text { GCAACACCACCACTGACG }\end{array}$ & $57^{\circ} \mathrm{C}$ & Mao et al., (2009) \\
\hline Hsalz-12 & $\begin{array}{l}\text { AAGCATCTATGAGGGGACAAA } \\
\text { AAAAATATGCTGCTGGAAGTT }\end{array}$ & $53.9^{\circ} \mathrm{C}$ & Ruas et al., (2009) \\
\hline
\end{tabular}

* PCR touchdown 


\section{DNA amplification using microsatellite primers}

Before the evaluation of the DNA sample with the microsatellite primers, the quality of the DNA was confirmed by the amplification using the ISSR (inter-simple sequence repeat) primer UBC808 following the protocol proposed by Rosa et al., (2017). Each DNA was only used for amplification with the microsatellite primers after successful amplification with the ISSR primers.

PCR amplification of DNA from each Asteraceae species using the heterologous microsatellite primer pairs was conducted in a final volume of $10 \mu \mathrm{L}$ containing: 1X PCR buffer, $3 \mathrm{mM} \mathrm{MgCl} 2,0.2 \mathrm{mM}$ dNTP, $0.8 \mathrm{mM}$ of each primer (forward and reverse), $0.04 \mathrm{U}$ of Taq DNA polymerase and $20 \mathrm{ng}$ of DNA, and ultrapure water to complete the volume. The amplification cycles were programmed as described in the original studies that first described each primer pair. In the first amplification test using each primer pair in each species, the annealing temperature described in the literature was used (Table 1). However, when non-specific amplification occurred using the temperatures proposed in the literature, the hybridization temperature was gradually increased by $2^{\circ} \mathrm{C}$ until specific amplification was obtained or until it reached $65^{\circ} \mathrm{C}$. Conversely, when there was no amplification, the temperature was gradually decreased by $2^{\circ} \mathrm{C}$ until amplification was obtained or until $45^{\circ} \mathrm{C}$ was attained.

The amplification products of all the species were separated by electrophoresis on $3 \%$ high resolution agarose gel at a constant voltage of $110 \mathrm{~V}$ for $4 \mathrm{~h}$ and then visualized under UV light by staining with ethidium bromide $\left(0.5 \mu \mathrm{g} / \mathrm{mL}^{-1}\right)$. The agarose used (Sigma-Aldrich, catalog number A4718) is ideal for the separation of small DNA fragments (e.g., PCR products) differing in size by as little as $2 \%$ and compares to the resolution of DNA in polyacrylamide gels. The size of the amplified fragments was determined using a standard molecular weight DNA ladder of $100 \mathrm{bp}$ increments.

After obtaining the results, all individuals that presented null alleles were submitted to a second analysis to confirm the null alleles. Also, the amplification product of at least three primers of each species which was monomorphic on the agarose gel was evaluated on polyacrylamide gels to confirm the monomorphic pattern of the locus. The $6 \%$ polyacrylamide gel was submitted to electrophoresis at a constant current of $1500 \mathrm{~V}$ for $4 \mathrm{~h}$ and the amplification products visualized by silver nitrate staining.

\section{Data analysis}

The gels were visually evaluated for the presence or absence of alleles. The percentage of amplification per species was calculated based on the number of primers pairs that amplified products in each species out of the total number of markers. From the matrices generated, we calculated the percentage of null alleles and polymorphisms.

The markers that amplified fragments of the expected sizes were considered transferred, but only those that presented polymorphism and absence of null alleles 
were considered useful for genetic-population studies. Primers were considered nontransferrable when PCR resulted in non-amplification or non-specific amplification after testing several annealing temperatures.

\section{RESULTS}

For most of the microsatellite markers, it was necessary to change the annealing temperature to obtain higher quality amplification products. The temperatures varied between 48 and $55^{\circ} \mathrm{C}$ for different loci and species (Table 2). Based on the criteria for data analysis, the highest percentage of transferability was $66.6 \%$ for $B$. articulata, and the lowest was $26.6 \%$ for $S$. brasiliensis (Table 2). The primer pairs SS20E, SS24F, Eari4-5, and Eari4-6 were transferred to all four species tested (Table 2). In contrast, markers 23(TG) $3+7 \mathrm{st}, \mathrm{Amb} 82$, and $\mathrm{Sg}-6$ were not transferred to any species (Table 2). The markers 19 and $\mathrm{CO} 227$ were transferred only to $B$. articulata and presented monomorphic and polymorphic amplification products, respectively (Table 2 ).

Table 2. Parameters of the 15 microsatellite loci for four tropical Asteraceae species. FR: fragment range in base pairs; $\mathrm{T}{ }^{\circ} \mathrm{C}$ : annealing temperature in degrees Celsius; NA: number of alleles; -: Not amplified; \% $\%$ : Percentage of transferability; \% P: Percentage of polymorphic loci.

\begin{tabular}{|c|c|c|c|c|c|c|c|c|c|}
\hline \multirow[t]{2}{*}{ Loci } & \multirow[t]{2}{*}{ FR } & \multicolumn{2}{|c|}{$\begin{array}{l}\text { Baccharis } \\
\text { articulata }\end{array}$} & \multicolumn{2}{|c|}{$\begin{array}{l}\text { Baccharis } \\
\text { milleflora }\end{array}$} & \multicolumn{2}{|c|}{$\begin{array}{l}\text { Baccharis } \\
\text { dracunculifolia }\end{array}$} & \multicolumn{2}{|c|}{$\begin{array}{l}\begin{array}{l}\text { Senecio } \\
\text { brasiliensis }\end{array} \\
\end{array}$} \\
\hline & & $\mathrm{T}^{\circ} \mathrm{C}$ & NA & $\mathrm{T}^{\circ} \mathrm{C}$ & NA & $\mathbf{T}^{\circ} \mathrm{C}$ & NA & $\mathbf{T}^{\circ} \mathrm{C}$ & NA \\
\hline SS20E & $273-299$ & 48 & $2^{b}$ & 48 & $2^{b}$ & 48 & $1^{\mathrm{a}}$ & 48 & $2 b$ \\
\hline $\mathrm{SS} 24 \mathrm{~F}$ & $156-222$ & 55 & $2 b$ & 55 & $1^{\mathrm{a}, \mathrm{b}}$ & 55 & $1^{\mathrm{a}, \mathrm{b}}$ & 55 & $2 b$ \\
\hline Eari4-5 & $212-362$ & 50 & $1^{\mathrm{a}, \mathrm{b}}$ & 50 & $1^{\mathrm{a}, \mathrm{b}}$ & 50 & $2 b$ & 50 & $1^{\mathrm{a}, \mathrm{b}}$ \\
\hline Eari4-6 & $207-295$ & 55 & $1^{\mathrm{a}, \mathrm{b}}$ & 55 & $3 b$ & 55 & $1^{\mathrm{a}}$ & 55 & $2 \mathrm{~b}$ \\
\hline 19 & $148-160$ & 50 & $1^{\mathrm{a}, \mathrm{b}}$ & 50 & - & 50 & - & 50 & - \\
\hline CO189 & $159-173$ & 55 & $1^{\mathrm{a}, \mathrm{b}}$ & 55 & - & 55 & $1^{\mathrm{a}, \mathrm{b}}$ & 55 & - \\
\hline $\mathrm{CO} 227$ & $193-219$ & 55 & $2^{\mathrm{b}}$ & 55 & - & 55 & - & 55 & - \\
\hline 23 (TG) $3+7 \mathrm{st}$ & $153-207$ & 50 & - & 50 & - & 50 & - & 50 & - \\
\hline $\mathrm{Amb} 82$ & $120-150$ & $*$ & - & $*$ & - & $*$ & - & $*$ & - \\
\hline $\mathrm{Sg}-2$ & $167-248$ & $*$ & $1^{\mathrm{a}, \mathrm{b}}$ & $*$ & - & $*$ & - & $*$ & - \\
\hline $\mathrm{Sg}-6$ & $200-244$ & $*$ & - & $*$ & - & $*$ & - & $*$ & - \\
\hline Sg-8 & $126-172$ & $*$ & - & * & $2 b$ & * & $1^{\mathrm{a}, \mathrm{b}}$ & $*$ & - \\
\hline ER-HAJZC & $179-195$ & $*$ & $3^{\mathrm{b}}$ & $*$ & $2 b$ & $*$ & $2 b$ & $*$ & - \\
\hline LHO35 & $170-210$ & 57 & - & 57 & - & 57 & $2 b$ & 57 & - \\
\hline HSALZ-12 & $100-350$ & 50 & $1^{\mathrm{a}, \mathrm{b}}$ & 50 & - & 50 & - & 50 & - \\
\hline$\% \mathrm{~T}$ & & & 66.6 & & 40.0 & & 53.3 & & 26.6 \\
\hline$\% \mathrm{P}$ & & & 40.0 & & 66.7 & & 37.5 & & 75.0 \\
\hline
\end{tabular}

The percentage of polymorphic loci ranged from $37.5 \%$ in $B$. dracunculifolia to $75.0 \%$ in $S$. brasiliensis. The amplification patterns of some of the primers evaluated in Asteraceae species are shown in Figure 1. The polyacrylamide gel analysis confirmed the amplification pattern observed on 3\% high resolution agarose gel for all primers tested. 

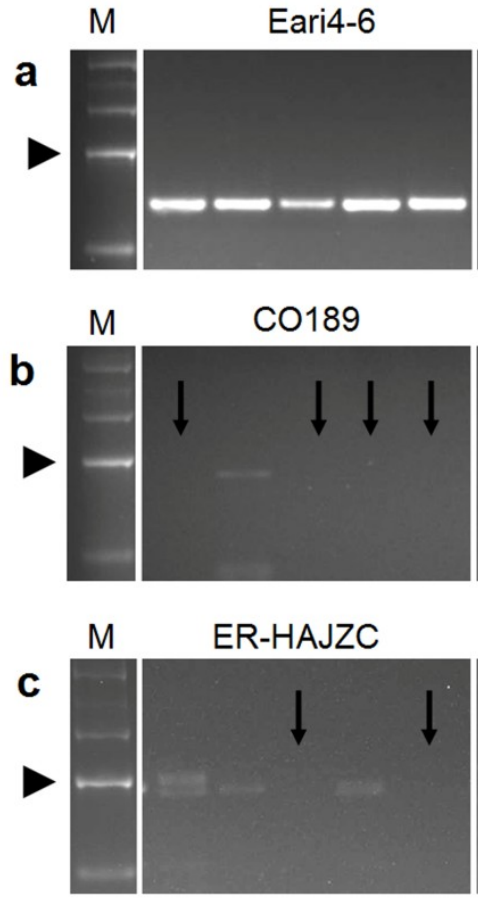

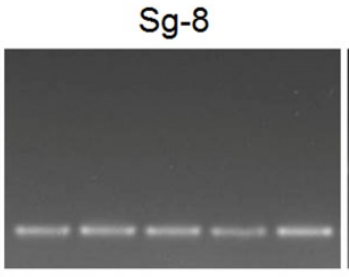

Eari4-6

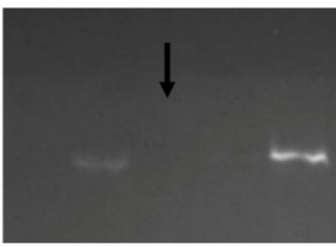

$\mathrm{CO} 227$

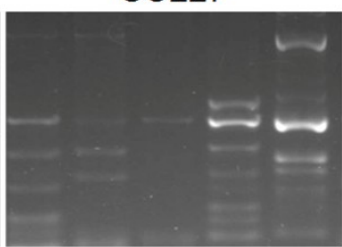

SS20E

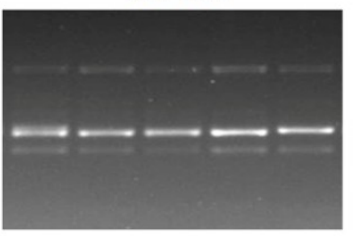

SS20E

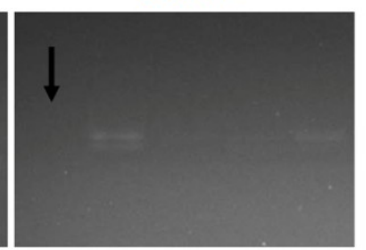

SS20E

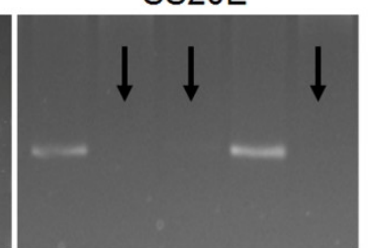

Figure 1. Agarose gels with amplification patterns of some microsatellite primers tested in Asteraceae. (a) Amplification pattern in Baccharis dracunculifolia. (b) Amplification pattern in Baccharis milleflora. (c) Amplification pattern in Baccharis articulata. The arrows indicate the null alleles. $\mathrm{M}$ indicates the molecular weight marker DNA Ladder valid for all gels in the row. The arrowheads to the left of the figures indicate the 200-bp band of the DNA Ladder.

\section{DISCUSSION}

\section{Transferability}

The use of microsatellite primers designed for a certain taxon as successful alternative markers in other species for which no primers are available has already been evaluated (Barbará et al., 2007; Varshney et al., 2007; Santos et al., 2010). This strategy has been applied in different taxa, and the results show that the closer related the species, the higher is the rate of transferability (Rosseto et al., 2000; Barbará et al., 2007; Ellis and Burke, 2007). The data obtained in our study suggests that this assessment is also valid for Asteraceae. In Asteraceae, the tribe level, which was the lowest taxonomic level evaluated among the species, had the highest rate of transferability.

In the eudicotyledons, the average rate of transferability has been estimated at approximately $70 \%$ within genera, which decreases to approximately $55 \%$ within the family (Barbará et al., 2007). However, among the species of the Asteraceae tested in our work, the transferability rates were lower than these values for most species. Of the seven Asteraceae species evaluated, only two had transfer rates greater than $50 \%$ ( $B$. articulata and $B$. dracunculifolia). Few genetic-population studies have used transferred markers to study the native tropical species of Asteraceae (Genton et al., 2005; Yu and Li, 2013; Belini et al., 
2016). Most of the primers developed for this family are for species of economic interest (Rakoczy-Trojanowska and Bolibok, 2004; Parmar et al., 2015); however, transferability has also been evaluated for cultivated species (Ellis and Burke, 2007). The first works that evaluated the transferability of markers for native species of Asteraceae reported the difficulty of heterologous amplification with microsatellite markers (Whitton et al., 1997), which may have discouraged more systematic transferability works with the native species of this family.

Heterologous amplification of microsatellites may be affected by a number of factors, such as genome size and complexity, life forms and reproduction, and each species different evolution rates (Whitton et al., 1997; Barbará et al., 2007); all of these factors influence how much each species differs in its DNA sequences when compared to another species within its group. In addition, transferability rates may also be determined by other factors. In a review of studies on the cross-species transfer of nuclear microsatellite primers in plants, transferable markers were found for only 88 tropical species while 243 were found for temperate species, despite the fact that approximately half of the source species in the reviewed studies were tropical (Barbará et al., 2007). This observation may be because tropical species are more genetically divergent from each other than temperate species (Hamrick,1996; Barbará et al., 2007) making marker transferability more difficult in the former. Thus, differentiated characteristics of tropical plant species probably play a role in the low transferability rates we observed in tropical Asteraceae species.

The evolution of herbaceous plants is considered one of the main innovations in the evolution of angiosperms; within the evolutionary timescale, they may be in a phase of early and faster diversification (Eriksson and Bremer, 1992; Hamrick, 1996). In such a phase, even if they are phylogenetically closely related species may be undergoing expressive differentiation of their DNA sequences. Specifically, the Asteraceae has been reported to have an excessively high diversification rate which provides high diversity in species (Kuzoff and Gasser, 2000). These characteristics suggest that the low transferability observed in our study has a contribution of the higher differentiation in DNA sequences in the Asteraceae when compared to the families compiled by Ellis and Burke (2007) that presented high transferability rates.

\section{Utility of transferable markers}

For transferred microsatellite markers to be useful for genetic-population studies, they need to show consistent amplification and polymorphism when used to evaluate populations (Fagundes et al., 2016; Rosa et al., 2017). We used 19 to 25 plants from each Asteraceae species and observed that even when the primers yielded amplification products (positive transferability), these were either monomorphic or included a high number of null alleles (Table 2). The presence of null alleles is a serious problem when interspecific primers are used. These alleles are not amplified via PCR and therefore are not detected in genotyping, leading to an overestimation of homozygotes (Aldrich et al., 1998; White et al., 1999; Pashley et al., 2006). Moreover, when the only type of polymorphism observed is in null alleles, the calculation of the genetic diversity indexes of a population is imprecise. In this case, the marker starts behaving like a dominant marker, where only two alleles are observed (presence or absence of a band). 
The main feature of microsatellite markers explored in population genetic studies is codominance; thus, this type of marker is used to estimate the levels of heterozygosity and gene flow, important genetic indexes in population genetics studies. If microsatellite marker are unable to identify heterozygotes, then the use of dominant markers such as ISSR (InterSimple Sequence Repeat) or AFLP (Amplified Fragment Length Polymorphism) are indicated. These markers are universal and have low development costs (Nybom, 2004). Furthermore, they amplify several loci with the same amplification cost of a microsatellite marker that in the case of null allele, amplifies only one locus. Therefore, to obtain geneticpopulation data of native tropical species of Asteraceae, we suggest that either specific microsatellite primers be developed, or dominant markers be used, as the current set of markers is not transferable.

Null alleles have rarely been detected when few individuals were used in transferability tests. Notably, in most studies that developed microsatellite primers, the authors tested these primers on a small number of samples from other species, which may falsely confirm their transferability. In our work, as discussed earlier, when transferability is based only on successful amplification, many primers were concluded to be transferred. However, further analysis of these transferred primers in populations showed high rates of monomorphism and / or null alleles. This behavior of heterologous microsatellite primers in tropical Asteraceae species has already been observed in Achyrocline flaccida (Weinm.) DC. (Rosa et al., 2017).

The overall analysis of our data lead us to conclude that the use of a low number of individuals (less than five) in transferability tests may lead to misleading conclusions regarding the usefulness of a transferred microsatellite marker for population genetic studies in related species.

\section{ACKNOWLEDGMENTS}

This study was financed in part by the Coordenação de Aperfeiçoamento de Pessoal de Nível Superior - Brasil (CAPES) - Finance Code 001.

\section{CONFLICTS OF INTEREST}

The authors declare no conflict of interest.

\section{REFERENCES}

Agostini F, Santos ACA, Rossato M, Pansera MR, et al. (2005). Estudo do óleo essencial de algumas espécies do gênero Baccharis (Asteraceae) do sul do Brasil. Rev. Bras. Farmacogn. 15: 215-220. https://doi.org/10.1590/S0102$695 X 2005000300010$.

Aldrich PR, Hamrick JL, Chavarriaga P and Kochert G (1998). Microsatellite analysis of demographic genetic structure in fragmented populations of the tropical tree Symphonia globulifera. Mol. Ecol. 7: 933-944. https://doi.org/10.1046/j.1365-294x.1998.00396.x

Barbará T, Palma-Silva C and Paggi GM (2007). Cross-species transfer of nuclear microsatellite markers: potential and limitations. Mol. Ecol. 16: 3759-3767. https://doi.org/10.1111/j.1365-294X.2007.03439.x

Beck JB, Semple JC, Brull JM, Lance SL, et al. (2014). Genus-wide microsatellite primers for de goldenrods (Solidago; Asteraceae). Appl. Plant. Sci. 2(4): apps.1300093. http://dx.doi.org/10.3732/apps.1300093

Belini CMB, Marques MOM, Figueira GM, Bajay MM, et al. (2016). Characterization of microsatellite markers for Baccharis dracunculifolia (Asteraceae). Appl. Plant. Sci. 4: 1-8. http://dx.doi.org/10.3732/apps.1500093.

Bittencourt JVM and Sebbenn AM (2009). Genetic effects of forest fragmentation in high-density Araucaria angustifolia populations in Southern Brazil. Tree Genet. Genomes. 5: 573-582. https://doi.org/10.1007/s11295-009-0210-4. 
Brandão MM, Vieira FA and Carvalho D (2011). Fine-scale genetic structure of Myrcia splendens (Myrtaceae). Rev. Árvore. 35: 957-964. http://dx.doi.org/10.1590/S0100-67622011000600001.

Da-Silva PR, Milach SCK and Tisian LM (2011). Transferability and utility of white oat (Avena sativa) microsatellite markers for genetic studies in black oat (Avena strigosa). Genet. Mol. Res. 4: 2916-292. http://dx.doi.org/10.4238/2011.November.29.2.

Doyle JJ and Doyle JL (1987). A rapid DNA isolation procedure for small quantities of fresh leaf tissue. Phytochem. Bull. 19:11-15.

Ellis JR and Burke JM (2007). EST-SSRs as a resource for population genetic analyses. Heredity. 99: 125-132. https://doi.org/10.1038/sj.hdy.6801001.

Eriksson O and Bremer B (1992). Pollination systems, dispersal modes, life forms, and diversification rates in angiosperm families. Evolution. 46: 258-266. https://doi.org/10.2307/2409820.

Fagundes BS, Silva LF, Giacomin RM, Secco D, et al. (2016). Transferability of microsatellite markers among Myrtaceae species and their utility to obtain population genetics data to help the conservation of the Brazilian Atlantic Forest. Trop. Conserv. Sci. 9: 408-422. https://doi.org/10.1177/194008291600900122.

Faria DA, Mamani EMC, Pappas MR, Pappas GJ, et al. (2010). A Selected Set of EST-Derived Microsatellites, Polymorphic and Transferable across 6 Species of Eucalyptus. J. Hered. 101: 512-520. https://doi.org/10.1093/jhered/esq024.

Ferreira-Ramos R, Accoroni KAG, Rossi A, Guidugli MC, et al. (2014). Genetic diversity assessment for Eugenia uniflora L., E. pyriformis Cambess., E. brasiliensis Lam. and E. francavilleana O. Berg. neotropical tree species (Myrtaceae) with heterologous SSR markers. Genet. Resour. Crop. Evol. 61: 267-272. https://doi.org/10.1007/s10722-013-0028-7.

Genton BJ, Jonot O, Thévenet D, Fournier E, et al. (2005). Isolation of five polymorphic microsatellite loci in the invasive weed Ambrosia artemisiifolia (Asteraceae) using an enrichment protocol. Mol. Ecol. Notes. 5: 381-383. http://dx.doi.org/10.1111/j.1471-8286.2005.00934.x.

Habermehl GG, Martz W, Tokarnia CH, Dobereiner J, et al. (1988). Livestock poisoning in South America by species of the Senecio plant. Toxicon. 26: 275-86. https://doi.org/10.1016/0041-0101(88)90218-8.

Hamrick JL (1996). Effects of life history traits on genetic diversity in plant species. Philos. Trans. R. Soc. Lond. B Biol. Sci. 351: 1291-1298. https://doi.org/10.1098/rstb.1996.0112.

Heiden G, Iganci JRV and Macias L (2009). Baccharis sect. Caulopterae (Asteraceae, Astereae) no Rio Grande do Sul, Brasil. Rodriguésia. 60: 943-983. https://doi.org/10.1590/2175-7860200960411.

Jonsson J, Wellenreuther $\mathrm{M}$ and Torbjorn $\mathrm{T}$ (2010). Ten polymorphic microsatellite markers for Hieracium s.s. (Asteraceae). Conserv. Genet. Res. 2: 295-300. http://dx.doi.org/10.1007/s12686-010-9209-2.

Kuleung C, Baenziger PS and Dweikat I (2004). Transferability of SSR markers among wheat, rye, and triticale. Theor. Appl. Genet. 108: 1147-1150. https://doi.org/10.1007/s00122-003-1532-5.

Kuzoff RK and Gasser CS (2000). Recent progress in reconstructing angiosperm phylogeny. Trends Plant. Sci. 5: 330336. https://doi.org/10.1016/S1360-1385(00)01685-X.

Lemos M, Barros MP, Sousa JPB, Silva Filho AA, et al. (2007). Baccharis dracunculifolia, the main botanical source of Brazilian green propolis, displays antiulcer activity. J. Pharm. Pharmacol. 59: 603-608. https://doi.org/10.1211/jpp.59.4.0017.

Liebsch D, Marques MCM and Goldenberg R (2008). How long does the Atlantic Rain Forest take to recover after a disturbance? Changes in species composition and ecological features during secondary succession. Biol. Cons. 141: 1717-1725. https://doi.org/10.1016/j.biocon.2008.04.013.

Lindsay DL, Bailey P, Anderson JL, Jung MG, et al. (2012). Isolation and characterization of microsatellite loci for a hyper-rare cliff endemic, Erigeron lemmonii, and a more widespread congener, Erigeron arisolius (Asteraceae). Conserv. Genet. Res. 4:849-852. http://dx.doi.org/10.1007/s12686-012-9657-y.

Lopes LE and Gonzaga LP (2014). Taxonomy, distribution, natural history and conservation of the Russet-mantled Foliage-gleaner Syndactyla dimidiata (Pelzeln, 1859) (Aves: Furnariidae). Zootaxa. 3754: 435-449. https://doi.org/10.11646/zootaxa.3754.4.5.

Lynch M and Milligan BG (1994). Analysis of population genetic structure with RAPD markers. Mol. Ecol. 3: 91-99. https://doi.org/10.1111/j.1365-294X.1994.tb00109.x.

Mao C, Pan Y, Wang J and Gong X (2009). Isolation and characterization of microsatellite markers for Ligularia hodgsonii Hook. (Asteraceae). Conserv. Genet. 10: 1853-1855. http://dx.doi.org/10.1007/s10592-009-9833-0.

Mittermeier RA, Robles, Gil, P, Hoffmann M, et al. (2004). Hotspots revisited: Earth's biologically richest and most endangered terrestrial ecoregions. CEMEX/Agrupación Sierra Madre, Mexico City.

Miwa M, Tanaka R, Shinone M, Kojima K, et al. (2000). Development of polymorphic microsatellite markers in a tropical tree species, Melaleuca cajuputi (Myrtaceae). Mol. Ecol. 9: 639-640. https://doi.org/10.1046/j.13565294x.2000.00882-6.x.

MMA Ministério do Meio Ambiente (2018). Área da Mata Atlântica é habitada por 70\% da população brasileira, MMA, Brasília, http://www.mma.gov.br/informma/item/9818 (Accessed on sept 12 2018). 
Nogueira AM, Ferreira A and Ferreira MFS (2015). Transferability of Microsatellites from Psidium guajava to Eugenia, Myrciaria, Campomanesia, and Syzygium Species (Myrtaceae). Plant Mol. Biol. Report. 34: 249-256. https://doi.org/10.1007/s11105-015-0921-7.

Nybom H (2004). Comparison of different nuclear DNA markers for estimating intraspecific genetic diversity in plants. Mol. Ecol. 13: 1143-1155. https://doi.org/10.1111/j.1365-294X.2004.02141.x.

Oliveira EJ, Pádua JG, Zucchi MI, Vencovsky R, et al. (2006). Origin, evolution and genome distribution of microsatellites. Genet. Mol. Biol. 29: 294-307. http://dx.doi.org/10.1590/S1415-47572006000200018.

Parmar EK, Fougat RS, Patel CB, Zala HN, et al. (2015). Validation of dbEST-SSRs and transferability of some other solanaceous species SSR in ashwagandha [Withania Somnifera (L.) Dunal]. 3Biotech. 5: 933-938. https://doi.org/10.1007/s13205-015-0295-4.

Pashley CH, Ellis JR, McCauley DE and Burke JM (2006). EST databases as a source for molecular markers: Lessons from the Helianthus. J. Hered. 97: 381-388. https://doi.org/10.1093/jhered/es1013.

Rakoczy-Trojanowska M and Bolibok H (2004). Characteristics and a comparison of three classes of microsatellitebased markers and their application in plants. Cell Mol. Biol. Lett. 9: 221-238.

Ribeiro MC, Metzger JP, Martensen AC, Ponzoni FJ, et al. (2009). The Brazilian Atlantic Forest: How much is left, and how is the remaining forest distributed? Implications for conservation. Biol. Cons. 142: 1144-1156. https://doi.org/10.1016/j.biocon.2009.02.021.

Rosa J, Weber GG, Cardoso R, Górski F, et al. (2017). Variability and population genetic structure in Achyrocline flaccida (Weinm.) DC., a species with high value in folk medicine in South America. PLoS one. 12(8): e0183533. https://doi.org/10.1371/journal.pone.0183533.

Rossetto M, Harriss FCL, Mclauchlan A and Henry RJ (2000). Interspecific amplification of Tea Tree (Melaleuca alternifolia - Myrtaceae) microsatellite loci potential implications for conservation studies. Aust. J. Bot. 48: 367373. https://doi.org/10.1071/BT98084.

Ruas CF, Nakayama TJ, Ortiz MA, Kuroki MA, et al. (2009). Isolation and characterization of eight microsatellite loci from the endangered plant species Hypochaeris salzmanniana (Asteraceae). Conserv. Genet. 10: 1413-1416. http://dx.doi.org/10.1007/s10592-008-9749-0.

Sala OE, Chapin FS, Armesto JJ, Berlow E, et al. (2000). Global biodiversity scenarios for the year 2100. Science. 287: 1770-1774. https://doi.org/10.1126/science.287.5459.1770.

Santos CAF, Oliveira VR and Rodrigues MA (2010). Caracterização molecular de cultivares de cebola com marcadores microssatélites. Pesq. Agropec. Bras. 45: 49-55. https://doi.org/10.1590/S0100-204X2010000100007.

Stehmann JR, Forzza RC, Salino A, Sobral M, et al. (2009). Plantas da Floresta Atlântica. Instituto de Pesquisa Jardim Botânico do Rio de Janeiro, Rio de Janeiro.

Takayama K, López-Sepúlveda P, Kohl G, Novak J, et al. (2012). Development of microsatellite markers in species of Erigeron (Asteraceae) endemic to the Juan Fernandez Archipelago, Chile. Am. J. Bot. 99: 487-489. http://dx.doi.org/10.3732/ajb.1200218.

Varshney RK, Thudi M, Aggarwal R and Börner A (2007). Genomics-assisted crop improvement: genomics approaches and platforms. Springer, Dordrecht.

White GM, Boshier DH and Powell W (1999). Genetic variation within a fragmented population of Swietenia humilis Zucc. Mol. Ecol. 8: 1899-1909. https://doi.org/10.1046/j.1365-294x.1999.00790.x.

Whitton J, Rieseberg LH and Ungerer MC (1997). Microsatellite loci are not conserved across the Asteraceae. Mol. Biol. Evol. 14: 204-209. https://doi.org/10.1093/oxfordjournals.molbev.a025755.

Wieczorek AM and Gerber MA (2002). Microsatellite loci for studies of population differentiation and range expansion in Solidago sempervirens L. (Asteraceae). Mol. Ecol. Notes. 2: 554-556. http://dx.doi.org/10.1046/j.14718286.2002.00316.x.

$\mathrm{Yu} \mathrm{X}$ and Li Q (2013). Isolation and chacaracterization of microsatellite markers for a worldwide invasive weed, Chromolaena odorata (Asteraceae). Am. J. Bot. 98: 259-261. http://dx.doi.org/10.3732/ajb.1100169.

Zucchi MI, Brondani RPV, Pinheiro JB, Chaves LJ, et al. (2003). Genetic structure and gene flow in Eugenia dysenterica DC. in the Brazilian Cerrado utilizing SSR markers. Genet. Mol. Biol. 26: 449-457. http://dx.doi.org/10.1590/S1415-47572003000400008. 